\title{
Effects of Rainfall on the Antimicrobial Activity and Secondary Metabolites Contents of Leaves and Fruits of Anadenanthera col- ubrina from Caatinga Area.
}

Daniel Rodrigo Cavalcante de Araújo', Luís Cláudio Nascimento da Silva², Wolfgang Harand³, Júlia Morais Fernandes, Thaciane da Cunha Soares ${ }^{4}$, Silvana Maria Zucolotto Langassner ${ }^{4}$, Raquel Brandt Giordani ${ }^{4}$, Rafael Matos Ximenes ${ }^{5}$, Alexandre Gomes da Silva ${ }^{6}$, Márcia Vanusa da Silva ${ }^{1}$, Maria Tereza dos Santos Correia ${ }^{1 *}$

\begin{abstract}
Daniel Rodrigo Cavalcante de
Araújo', Luís Cláudio Nascimento da Silva ${ }^{2}$, Wolfgang Harand ${ }^{3}$, Júlia Morais Fernandes ${ }^{4}$, Thaciane da Cunha Soares ${ }^{4}$, Silvana Maria Zucolotto Langassner ${ }^{4}$, Raquel Brandt Giordani ${ }^{4}$, Rafael Matos Ximenes ${ }^{5}$, Alexandre Gomes da Silva', Márcia Vanusa da Silva', Maria Tereza dos Santos Correia ${ }^{{ }^{*}}$

'Laboratório de Produtos Naturais, Departamento de Bioquímica, Universidade Federal de Pernambuco, Pernambuco, BRASIL. 2Programa de Mestrado em Biologia Parasitária, Universidade CEUMA, Maranhão, BRASIL.

${ }^{3}$ Laboratório de Fitoquímica, Instituto Nacional do Semi-Árido (INSA), Paraíba, BRASIL. 'Laboratório de Farmacognosia, Departamento de Farmácia, Universidade Federal do Rio Grande do Norte, Rio Grande do Norte, BRASIL.

${ }^{5}$ Laboratório de Farmacognosia, Departamento de Antibióticos, Universidade Federal de Pernambuco, Pernambuco, BRASIL.
\end{abstract}

\section{Correspondence}

Maria Tereza dos Santos Correia

Departamento de Bioquímica, Universidade Federal de Pernambuco, Pernambuco, BRASIL.

Phone number: +558121268540

Email: mtscorreia@gmail.com

History

- Submission Date: 18-10-2016;

- Review completed: 01-12-2016;

- Accepted Date: 18-12-2016.

\section{DOI : 10.5530/pj.2017.4.73}

Article Available online

http://www.phcogj.com/v9/i4

\section{Copyright}

(C) 2016 Phcog.Net. This is an openaccess article distributed under the terms of the Creative Commons Attribution 4.0 International license.

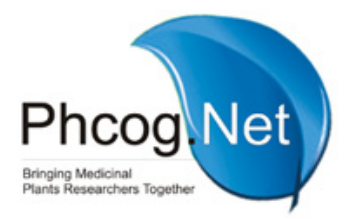

\begin{abstract}
Background: Anadenanthera colubrina (Vell.) Brenan var. cebil (Griseb) is a plant widely used for medicinal proposes in Brazilian Northeast. Objective: This study aimed to analyze the influence of rainfall indexes (RI) in antimicrobial activity and phytochemical constituents of extracts from leaves and fruits of $A$. colubrina. Material and Methods: Samples were collected in Catimbau National Park (Buíque, Pernambuco, Brazil) at September 2010 (RI: $75 \mathrm{~mm}$ ) and January (RI: $65 \mathrm{~mm}$ ), April (RI: $162 \mathrm{~mm}$ ) and June 2011 (RI: $73 \mathrm{~mm}$ ). The extracts were prepared by Soxhlet extraction using cyclohexane, chloroform, ethyl acetate and methanol. The antimicrobial activity was determined by MIC and MBC values. Results: All extracts showed antimicrobial activity, but ethyl acetate extracts (from all periods) were more active. Strong correlations were found between the RI and the average MIC of MLE ( $\rho$ : -0.99), EALE ( $\rho:-0.81)$, CHFE ( $\rho:-0.81)$, EAFE ( $\rho:-0.80)$; while moderate and weak correlations were found for other extracts. Through a HPLC analysis was possible to reveal that the samples collected from dry periods had more chemical diversity (as they presented more peaks). Gallic acid and quercetin (and derivative compounds) were identified. The levels of quercetin were enhanced in extracts from dry months. Conclusion: Our results showed that the rainfall has a positive effect on the antimicrobial activity of leaves and fruits of $A$. colubrina, however these extracts showed more chemical diversity during dry months.
\end{abstract}

Key words: Natural products, Semi arid area, Antimicrobial agents, Medicinal plants.

\section{INTRODUCTION}

The World Health Organization (WHO) has been drawing attention to the increasing problem of microbial resistance to conventional antibiotics for more than a decade. ${ }^{1}$ This scenario of antimicrobial resistance has encouraged research using medicinal plants, especially those from under-exploited biomes, such as the Caatinga. This is a unique biome from Northeast of Brazil where traditional communities use hundreds of plant species form medical purposes, such as the control of microbial infections. ${ }^{2,3}$ For some of those, scientific evidences confirm these therapeutic aptitudes. ${ }^{4-7}$ In recent years, the ethnomedicinal knowledge has stimulated several studies about the pharmaceutical potential of natural products of northeastern Brazil. ${ }^{8}$ This is justified by the fact that the intrinsic features of Caatinga area (drought, high solar radiation rates and other environmental stresses) influence the synthesis of secondary metabolites of its plants, ${ }^{9}$ making them attractive targets for bioprospecting programs. ${ }^{10}$ In traditional medicine, Anadenanthera colubrina (Vell.) Brenan var. cebil (Griseb) Alstchull (1964), popularly known as Angico (synonyms: Acacia cebil, Peptadenia macrocarpa, Anadenanthera macrocarpa), ${ }^{11}$ is frequently used by inhabitants of the Caatinga biome to treat anemia, cancer and inflammatory diseases. ${ }^{2,3}$ Previous studies demonstrated the antimicrobial potential of leaves and fruits of this plant, especially against Staphylococcus aureus. ${ }^{4-6,12}$ In this context, the present study aims to analyze the effects of rainfall on the antimicrobial activity and secondary metabolites contents of leaves and fruits of Anadenanthera colubrina. With this information, the best collection time to maximize the bioactive compounds extraction for medicinal purposes may be determined.

\section{MATERIAL AND METHODS}

\section{Plant material and extract preparation}

Leaves and fruits of a single individual of A. colubrina were collected at Catimbau National Park (Buíque, Pernambuco, Brazil) at September 2010 and January, April and June 2011. The rainfall index for this months were $75 \mathrm{~mm}, 65 \mathrm{~mm}, 162 \mathrm{~mm}$ and $73 \mathrm{~mm}$, respectively (as provided by Agronomic Institute of Pernambuco; IPA/PE). The voucher specimen (IPA 84.039) is deposited at IPA/PE. The plant material was dried at $45^{\circ} \mathrm{C}$ and after 3 days milled to a fine powder in a Macsalab Mill (Model 200 LAB, Eriez;, Bramley), and stored at room temperature in closed containers in the dark until used.

Cite this Article: Araújo DRC, Silva LCN, Harand W, Fernandes JM, Soares TC, Langassner SMZ, Giordani RB, Ximenes RM, Silva AG, Silva MV, Correia MTS. Effects of Rainfall on the Antimicrobial Activity and Secondary Metabolites Contents of Leaves and Fruits of Anadenanthera colubrina from Caatinga Area. Pharmacogn J. 2017;9(4):435-40. . 
Samples (100g) from each tissue were subjected to Soxhlet extraction using an eluotropic series of solvents in the following order: cyclohexane, chloroform, ethyl acetate and methanol. All samples were subjected to saturation at reflux for 24 hours. After this time, the extracts were filtered (Whatman filter paper No 1). Solvent was completely removed from all extracts from leaves (L) or fruits (F) (cyclohexane: ChLE and ChFE; chloroform: CLE and CFE; ethyl acetate: EALE and EAFE: methanol: MLE and MFE) on a rotating evaporator at $45^{\circ}$ under reduced pressure and stored for later antimicrobial and phytochemical analyses.

\section{Antimicrobial assays Microorganisms}

The microorganisms used in this work were provided by Culture Collection UFPEDA (Department of Antibiotics, UFPE), consisting of: Staphylococcus aureus (three strains; UFPEDA 02, 733 and 709), Bacillus subtilis (UFPEDA 86), Escherichia coli (UFPEDA 224), Klebsiella pneumoniae (UFPEDA 396) and Pseudomonas aeruginosa (UFPEDA 416).

\section{Determination of minimal inhibitory concentration (MIC) and minimum bactericidal concentration (MBC)}

The minimal inhibitory concentration (MIC) was determined by the microdilution method. ${ }^{12}$ Twofold serial dilutions of each extract (initial concentration: $50 \mathrm{mg} / \mathrm{mL}$ ) were prepared in Müller-Hinton broth (MHB) and $10 \mu \mathrm{L}$ of bacterial suspension (approximately $1.5 \times 10^{8} \mathrm{CFU} /$ $\mathrm{mL}$ ) were added. The samples were incubated for $24 \mathrm{~h}$ at $37^{\circ} \mathrm{C}$. Resazurin solution $(0.01 \%)$ was used as an indicator by color change visualization: any color changes from purple to pink were recorded as bacterial growth. The lowest concentration at which no color change occurred was taken as the MIC. Afterwards, cultures were seeded in MHA and incubated for $24 \mathrm{~h}$ at $37^{\circ} \mathrm{C}$ to determine the minimum bactericidal concentration (MBC), which corresponds to the minimum concentration of the sample that eliminated the bacteria.

\section{Phytochemical Analysis \\ Thin layer chromatography (TLC) analysis}

The qualitative phytochemical analysis was performed by Thin layer chromatography (TLC) using aluminum-precoated plates of silica gel 60 F254 (Merck') and adequate visualization techniques (Dragendorff, NEU-PEG, KOH-Ethanol, Liebermann-Burchard, vanillin-sulfuric acid and others reagents, according to the respective method). ${ }^{13}$

\section{High-performance liquid chromatography (HPLC) analysis}

Investigations of phenolic content were performed by a High-performance liquid chromatography system (HPLC; ProStar, Varian) which is comprised by a quaternary pump, diode array detector, auto-sampler. The reagents used were acetonitrile HPLC grade (Panreac ${ }^{\circ}$ ) and acetic acid $\left(\right.$ Vetec $\left.^{\oplus}\right)$. Water was purified through a milli-Q $\left(\right.$ Merck $\left.^{\oplus}\right)$ system. Phenolic compounds were analysed on a Phenomenex C18 column (250 $\mathrm{x} 4.6 \mathrm{~mm}, 5 \mu \mathrm{m})$, applying mobile phase gradient of acidified water $(0.3 \%$ acetic acid) (solvent A) and acetonitrile (B) as follows: Linear gradient from 10 to $20 \%$ (B) from 0 to $10 \mathrm{~min}$; and linear gradient from 20 to $28 \%$ (B) from 10 to $60 \mathrm{~min}$. The flow rate was kept constant at $0.8 \mathrm{~mL} / \mathrm{min}$ and detection was in the range of 190 to $450 \mathrm{~nm}$. Phenolic compounds were identified by comparison of their retention times and their absorption spectra of ultraviolet light (UV). Gallic acid, chlorogenic acid, ellagic acid, rutin and quecertin were used as standard compounds (all purchased from Sigma-Aldrich).

\section{Statistical analyses}

Statistical analyses were performed by One-way analysis of variance (ANOVA). All analyses were carried out using software Graph Prism, version 4 . The correlation indices were calculated using the Pearson coefficient $(\rho)$. Only for correlation between Rainfall Index and MIC values a negative $\rho$-value is considered as direct correlation.

\section{RESULTS}

\section{Effects of rainfall on the antimicrobial activity of Anadenanthera colubrina}

All extracts from of A. colubrina showed antimicrobial activity, being more active against gram-positive organisms (Table 1). Most tested bacteria were more sensitive to ethyl acetate extracts (from all periods). Taking into account the results for Gram-positive bacteria (all S. aureus strains and B. subtilis), ethyl acetate extracts from leaves showed the lowest average MIC values $(1.06 \mathrm{mg} / \mathrm{mL})$, this value was significantly lower than those observed for other extracts $(\mathrm{p}<0.05)$. In the same way, among fruits extracts, the lowest average of MIC values was found to ethyl acetate extracts $(17.50 \mathrm{mg} / \mathrm{mL})$, however no significant differences were observed between the results. For this reason, the ethyl acetate extracts were selected for chemical analysis.

Regarding the effect of the collection period on antimicrobial activity, the lowest MIC values were observed in the months with the highest rainfall index (RI) for extract from both tissues (Table 1). Strong correlations were found between the RI and the average MIC of MLE ( $\rho:-0.99)$, EALE ( $\rho:-0.81)$, CHFE ( $\rho:-0.81)$, EAFE ( $\rho:-0.80)$; moderate correlation was observed for CLE ( $\rho$ : -0.62); while weak correlations were found for CFE ( $\rho$ : -0.48), MFE ( $\rho:-0.42)$, and CHLE ( $\rho:-0.27)$.

\section{Effects of rainfall on phytochemical composition of Anadenanthera colubrina}

It was observed by TLC analysis that the ethyl acetate extracts from both tissues exhibited flavonoids, cinnamic derivatives, terpenes, cyanogenic glycosides and proanthocyanidins. Whereas TLC assays did not show qualitative differences between the extracts obtained from leaves or fruits (Table S1), we were able to detect 15 phenolic compounds with different retention time (Rt) and UV spectra in HPLC chromatograms. The presence and concentration of these compounds varied with tissue and rainfall index.

The extracts from fruits showed more compounds than those from leaves: peaks 2 and 5 were found at all fruits samples, EAFE1 had the highest chemical phenolic diversity as 13 peaks were detected and some compounds were only found in this sample (peaks 3 and 4). EAFE2, EAFE3 and EAFE4 showed 10 peaks. The concentration of some compounds also varied according to collection time. For example, peak 6 had maximum detection on September (EAFE1); while peaks 8, 12 and 15 apparently were more found in April and January (Figure 1). Regarding the qualitative results for leaf extracts, EALE2 showed the highest number of peaks (8). Only two peaks were specific for EALE2 (12 and 13) and peak 14 was only absent for EALE1; the other peaks were present in all extracts. However, quantitative differences for some compounds contents could also be observed, for example, peak 1 was larger in January, and peak 15 in September and January (Figure 1).

The identity of gallic acid (peak 1) and quercetin (peak 15) were confirmed by co-injection of an internal standard for each compound (Figure S1). Some compounds (peak 10 and 11) are presumably quercetin derivatives due to the close similarity in the UV absorption spectra (Figure S2). Gallic acid, quercetin (and its derivatives) had already been 

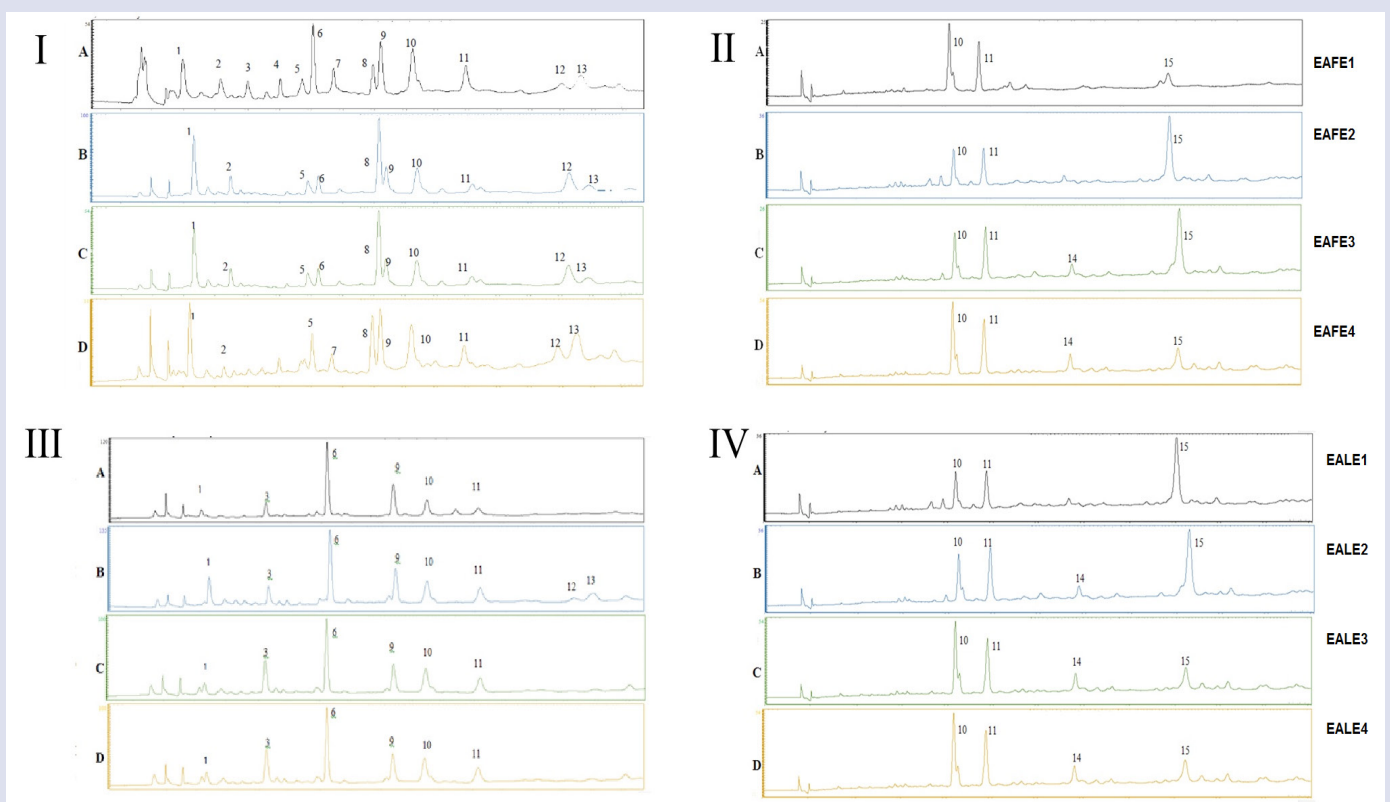

Figure 1: HPLC-UV chromatograms of phenolic compounds from ethyl acetate extracts of leaves and fruits of Anadenanthera colubrina collected at September 2010 (A), January 2011 (B), April 2011 (C), June 2011 (D). I: Chromatogram from fruits detected at $280 \mathrm{~nm}$; II: Chromatogram from fruits detected at $340 \mathrm{~nm}$; III: Chromatogram from leaves detected at $280 \mathrm{~nm}$; IV: Chromatogram from leaves detected at $340 \mathrm{~nm}$.

Table 1: Antimicrobial activity of ethyl acetate extracts from leaves and fruits of Anadenanthera colubrina.

\begin{tabular}{|c|c|c|c|c|c|c|c|c|c|}
\hline \multirow[t]{2}{*}{ Tissues } & \multirow[t]{2}{*}{ Strain } & \multicolumn{2}{|c|}{ September } & \multicolumn{2}{|c|}{ January } & \multicolumn{2}{|c|}{ April } & \multicolumn{2}{|c|}{ June } \\
\hline & & MIC & MBC & MIC & MBC & MIC & MBC & MIC & MBC \\
\hline \multirow[t]{8}{*}{ Leaves } & S. aureus 02 & 0.390 & 6.25 & 0.781 & 12.5 & 0.195 & 0.781 & 0.390 & 1.562 \\
\hline & S. aureus 733 & 0.781 & 3.125 & 0.781 & 25 & 0.390 & 0.781 & 6.25 & 12.5 \\
\hline & S. aureus 709 & 1.562 & 50 & 1.562 & $>50$ & 0.781 & 3.125 & 0.390 & 12.5 \\
\hline & E. coli & 6.25 & 6.25 & 6.25 & 50 & 0.390 & $>50$ & 6.25 & 25 \\
\hline & P. aeruginosa & 3.125 & 6.25 & 6.25 & 50 & 12.5 & 12.5 & 0.781 & 6.25 \\
\hline & B. subtilis & 0.781 & 1.5625 & 0.781 & 50 & 0.390 & 0.390 & 0.781 & $>50$ \\
\hline & K. pneumoniae & 25 & $>50$ & 25 & $>50$ & 1.562 & 6.25 & 25 & $>50$ \\
\hline & S. aureus 02 & 0.390 & 3.125 & 0.390 & 12.5 & 0.097 & 0.390 & 0.781 & $>50$ \\
\hline \multirow[t]{6}{*}{ Fruits } & S. aureus 733 & 0.781 & 3.125 & 1.562 & 6.25 & 0.390 & 0.781 & 1.562 & 3.125 \\
\hline & S. aureus 709 & 0.193 & 6.25 & 1.562 & 6.25 & 0.195 & 0.781 & 0.019 & 0.039 \\
\hline & E. coli & 6.25 & 6.25 & 6.25 & 6.25 & 0.195 & $>50$ & 6.25 & 6.25 \\
\hline & P. aeruginosa & 1.562 & 1.5625 & 1.562 & 3.125 & 6.25 & 12.5 & 6.25 & 6.25 \\
\hline & B. subtilis & 0.781 & 3.125 & 0.781 & 50 & 0.195 & 0.390 & 0.390 & 6.25 \\
\hline & K. pneumoniae & 25 & $>50$ & 25 & $>50$ & 0.781 & $>50$ & 6.25 & 6.25 \\
\hline
\end{tabular}

Results are expressed in $\mathrm{mg} / \mathrm{mL}$

Table S1: Phytochemical profile of ethyl acetates from leaves and fruits of Anadenanthera colubrina.

\begin{tabular}{|c|c|c|c|c|c|c|c|c|}
\hline \multirow{3}{*}{$\begin{array}{c}\begin{array}{c}\text { Class of secondary } \\
\text { metabolite }\end{array} \\
\text { Flavonoids }\end{array}$} & \multicolumn{8}{|c|}{ Anandenanthera colubrina var. Cebil } \\
\hline & \multicolumn{4}{|c|}{ Leaves } & \multicolumn{4}{|c|}{ Fruits } \\
\hline & ++ & ++ & ++ & ++ & ++ & ++ & ++ & ++ \\
\hline Cinnamic Acid Derivatives & traces & traces & traces & traces & ++ & ++ & ++ & ++ \\
\hline Triterpenes and Steroids & + & + & + & + & + & traces & traces & traces \\
\hline Mono and Sesquiterpenes & - & - & - & - & - & - & - & - \\
\hline Alkaloids & - & - & - & - & - & - & - & - \\
\hline Proanthocyanidins & ++ & ++ & ++ & ++ & +++ & +++ & +++ & +++ \\
\hline
\end{tabular}



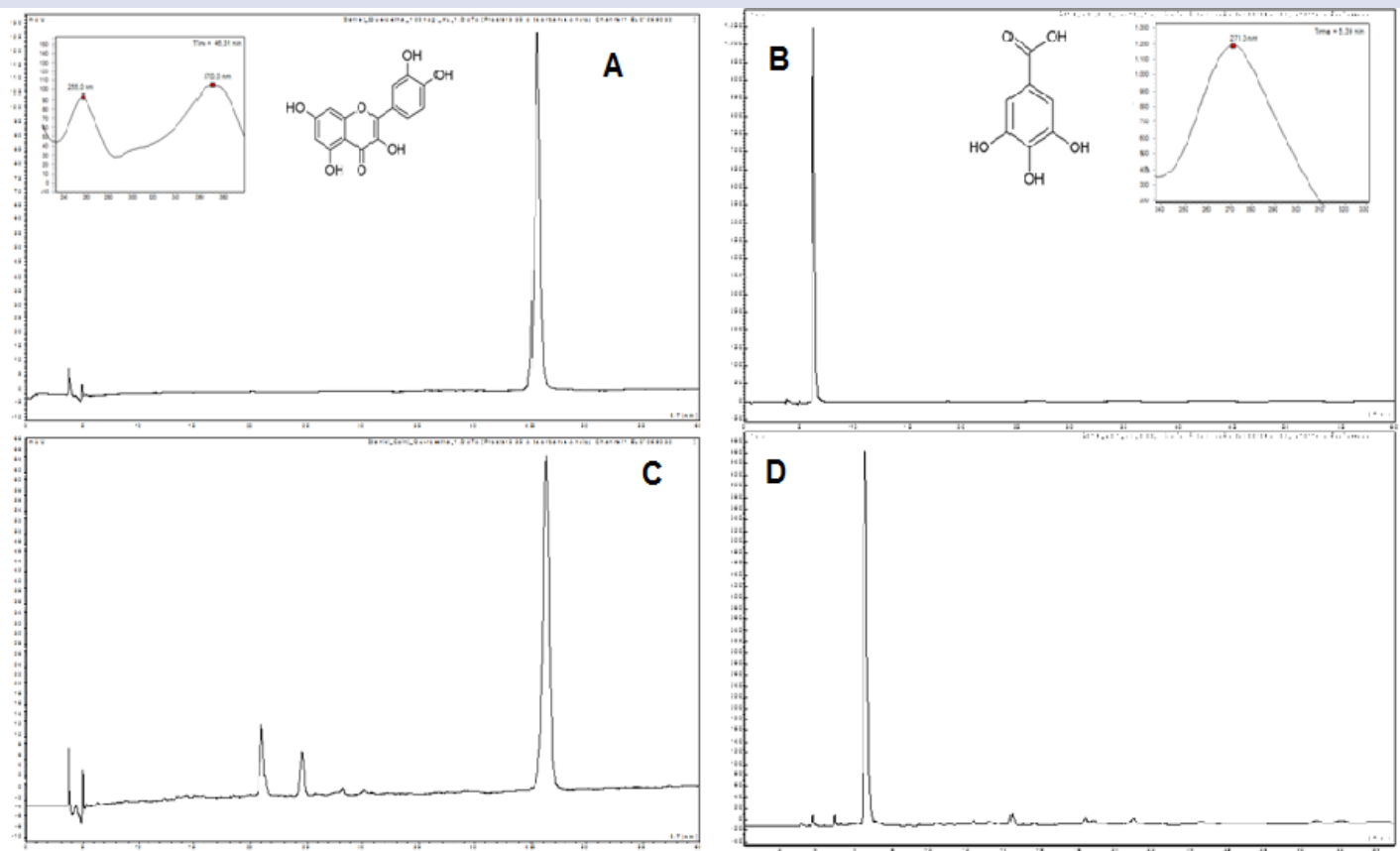

Figure S1: HPLC-UV chromatograms of quercetin (A), gallic acid (B), quercetin + ethyl acetate extracts of $A$. colubrina leaves (C) and gallic acid + ethyl acetate extracts of $A$. colubrina leaves (D). Detection at $340 \mathrm{~nm}$.
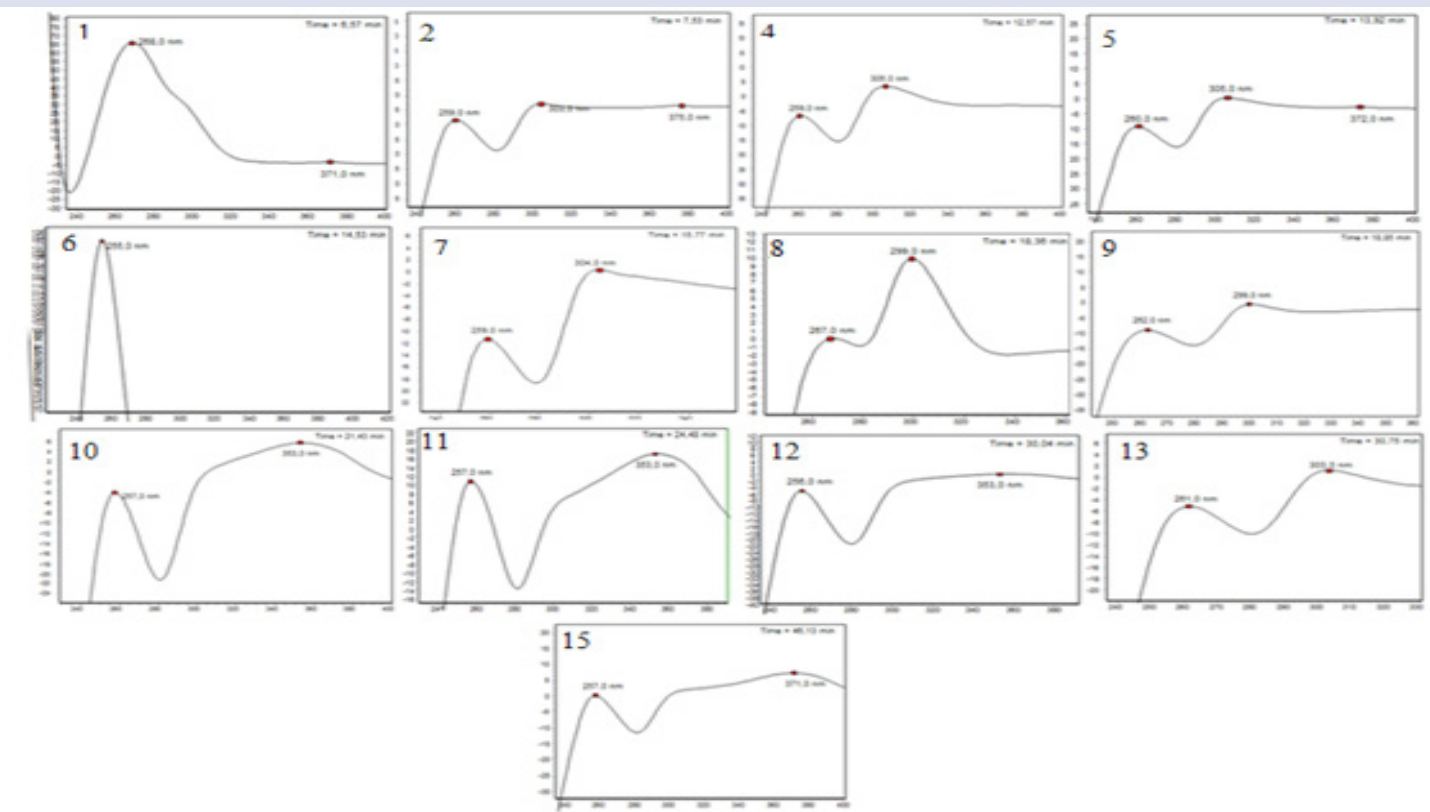

Figure S2: UV spectra analysis of the main peaks. Peak 1:gallic acid (UV 268nm); peaks 10 e 11: quercetin derivatives (UV 257 $353 \mathrm{~nm}$ ) and peak 15: quercetin (UV $257371 \mathrm{~nm}$ ).

detected in the extracts from A. colubrina. ${ }^{6,21}$ Antimicrobial activity of plants is commonly attributed to these compounds. ${ }^{14-16}$

\section{DISCUSSION}

This work analyzed the effects of rainfall on the antimicrobial action and phytochemical constituents of extracts from leaves and fruits of $A$. colubrina. This plant has been subject of several studies about its pharmaceutical potential. ${ }^{4-7,12,17}$ In our previous studies the antimicrobial action of extracts and fractions from leaves and fruits of A. colubrina was reported against Gram-positive bacteria, and no activity was observed against Gram negative bacteria. ${ }^{4-6,12}$ In the present work we employed a different extraction method, by which we obtained extracts with ac- tivity against tested Gram negative bacteria. Anyway, the best activity was found against $S$. aureus and B. subtilis, and ethyl acetate extracts had the best activity. It is also important to highlight that some variation on antimicrobial activity of products derived from A. colubrina has been found according with area of cultivation. For example, extracts derived of samples from Cerrado biome did not show antagonist activity, ${ }^{18}$ while others from Caatinga area were able to inhibit microbial grow. ${ }^{19}$

Since the production of secondary metabolites is influenced by environmental conditions (such as temperature, soil composition, solar irradiation, water availability), we attempted to evaluate the influence of rainfall on the antimicrobial action and chemical composition of extracts from both leaves and fruits. First we analyzed the variation on antimicrobial 
activity of those extracts. We correlated the RI for each month where the collection was performed with the MIC average obtained. Strong correlations were found for most of extracts. There is no consensus on the effect of rainfall index in the biological activity of plants, both positive and negative correlations are reported. ${ }^{20,21}$ Our results corroborate with several reports which showed positive effects of rainfall on the biological activity of plant extracts. ${ }^{20,21}$

The influence of rainfall on the phytochemical composition of A. colubrina extracts was first analyzed by TLC based assay. In general, we observed the same composition reported in our previous work. ${ }^{12}$ It was not noted qualitative differences between the extracts prepared in each period. Thus, we attempted to perform a HLPC analysis which revealed some quantitative differences: the samples collected from dry periods had more diversity (as they presented more peaks). Some compounds were identified: gallic acid (peak 1), quercetin (peak 15) and two quercetin derivatives (peaks 10 and 11). In addition, quercetin levels increased in those extracts from dry months. Enhanced levels of quercetin have been reported to other plants during dry seasons. ${ }^{22}$ The production of quercetin and other flavonoids was shown to be up-regulated during stressful conditions such as excessive ultra-violet radiation and high salinity. ${ }^{23}$ These findings could explain the well-known photoprotective effect of quercetin. ${ }^{24}$

\section{CONCLUSION}

Our results confirm that the rainfall levels have influence on the antimicrobial activity and chemical diversity of leaves and fruits of A. colubrina. Specifically, the antimicrobial activity was enhanced during months with higher rainfall levels, while the most chemical diversity was found in dry months. The increased levels of quercetin found in samples from dry months suggest metabolic alterations in order to produce compounds related to plant resistance during stressful conditions. These analyses may direct for the best collection time for obtain antimicrobial products derived from A. colubrina which can be applied for biomedical purposes.

\section{CONFLICT OF INTEREST}

Nil

\section{ACKNOWLEDGMENT}

The authors thank financial support from Conselho Nacional de Desenvolvimento Científico e Tecnológico (CNPq), Fundação de Amparo à Ciência e Tecnologia do estado de Pernambuco (FACEPE, AMD-01562.00/12) and Coordenação de Aperfeiçoamento de Pessoal de Nível Superior (CAPES).

\section{ABBREVIATIONS USED}

A. colubrina: Anadenanthera colubrina; B. subtillis: Bacillus subitilis; CFE: Chloroform Fruits Extract; CHFE: Cyclohexane Fruits Extract; CHLE: Cyclohexane Leaves Extrac; CLE: Chloroform Leaves Extract; E. coli: Escherichia coli; EAFE: Ethyl Acetate Fruits Extract; EAFE1: Ethyl Acetate Fruits Extract September; EAFE2: Ethyl Acetate Fruits Extract January; EAFE3: Ethyl Acetate Fruits Extract April; EAFE: Ethyl Acetate Fruits Extract June; EALE: Ethyl Acetate Leaves Extract; EALE1: Ethyl Acetate Leaves Extract September; EALE2: Ethyl Acetate Leaves Extract January; EALE3: Ethyl Acetate Leaves Extract April; EALE4: Ethyl Acetate Leaves Extract June; HPLC: High Performance Liquid Chromatography; IPA: Agronomic Institute of Pernambuco; K. pneumoniae: Klebsiella pneumoniae; MBC: Minimum Bactericidal Concentration; MFE: Methanol Fruits Extract; MIC: Minimal Inhibitory Concentration; MLE: Methanol Leaves Extract; P. aeruginosa: Pseudomonas aeruginosa; PE: Pernambuco; RI: Rainfall Indexes; Rt: Retention Time; S. aureus: Staphylococcus aureus; TLC: Thin Layer Chromatography; UFPEDA: Culture
Collection of Department of Antibiotics; UFPE: UV: Ultraviolet; WHO: World Health Organization.

\section{REFERENCES}

1. World Health Organization. The evolving threat of antimicrobial resistance: Options for action. World Health Organization. 2012:2:14-21.

2. Albuquerque UP, Medeiros PM, Almeida JM, Linsneto EMF, Melo JG, Santos JP, Santos JP. Medicinal plants of the caatinga (semi-arid) vegetation of NE Brazil: A quantitative approach. J. Ethnopharmacol. 2007;114(3):325-54. https://doi. org/10.1016/j.jep.2007.08.017 PMid:17900836.

3. Agra MF, Baracho GS, Nurit K, Basílio IJLD, Freitas PF, Barbosa-Filho JM. Survey of medicinal plants used in the region Northeast of Brazil. Rev. Bras. Farmacogn. 2008;18(3):472-508. https://doi.org/10.1590/S0102-695X2008000300023.

4. Da Silva LCN, Silva-Junior CA, Souza RM, Macedo AJ, Silva MV, Correia MTS. Comparative analysis of the antioxidant and DNA protection capacities of Anadenanthera colubrina, Libidibia ferrea and Pityrocarpa moniliformis. Food Chem. Toxicol. 2011:49:2222-8. https://doi.org/10.1016/j.fct.2011.06.019 PMid:21712063

5. Da Silva LCN, Sandes JM, Paiva MM, Araújo JM, Figueiredo RCBQ, Silva MV, Correia MTS. Anti-Staphylococcus aureus action of three Caatinga fruits evaluated by electron microscopy. Nat. Prod. Res. 2013;27:1492-6. https://doi.org/10 .1080/14786419.2012.722090 PMid:22974409

6. Da Silva LCN Miranda RCM, Gomes B Macedo AJ Araújo JM, Fiqueiredo RCBQ, Silva MV, Correia MTS. Evaluation of combinatory effects of Anadenanthera colubrina, Libidibia ferrea and Pityrocarpa moniliformis fruits extracts and erythromycin against Staphylococcus aureus. J. Med. Plants Res. 2013;7:2358 64.

7. Tretin DS, Silva DB, Amaral MW, Zimmer KR, Silva MV, Lopes NP, Giordani RB, Macedo, A. Tannins Possessing Bacteriostatic Effect Impair Pseudomonas aeruginosa Adhesion and Biofilm Formation. Plos One. 2013;8(6):66257. https:// doi.org/10.1371/journal.pone.0066257 PMid:23776646 PMCid:PMC3679062.

8. Saraiva ME, De Alencar Ulisses, AVR, Ribeiro DA, De Oliveira LGS, De Macêdo DG, De Sousa FDFS, De Almeida Souza MM. Plant species as a therapeutic resource in areas of the savanna in the state of Pernambuco, Northeast Brazil. J. Ethnopharmacol. 2015;171:141-53https://doi.org/10.1016/j.jep.2015.05.034 PMid:26026371.

9. Gobbo-Neto L, Lopes NP. Plantas Medicinais: Fatores de Influência no Conteúdo de Metabólitos Secundários. Quim. Nova. 2007;30(2):374-381. https:// doi.org/10.1590/S0100-40422007000200026.

10. Albuquerque UP, De Medeiros PM, Ramos MA, Júnior WSF, Nascimento ALB, Avilez WMT, De Melo J G. Are ethnopharmacological surveys useful for the discovery and development of drugs from medicinal plants? Rev. Bras. Farmacogn. . 2014;24(2):110-5. https://doi.org/10.1016/j.bjp.2014.04.003.

11. Queiroz, LP. Legumes of the Caatinga. Feira de Santana: Royal Botanic Garden Edinburg. 2009.p.440-3.

12. Araújo DRC, Da Silva LCN, Da Silva AG, Macedo AJ, Correia MTS, Da Silva MV. Comparative analysis of anti-Staphylococcus aureus action of leaves and fruits of Anadenanthera colubrina var.Cebil (Griseb.) Altschull. Afr. J. Microbiol. Res. 2014; 8(28):2690-6. https://doi.org/10.5897/AJMR2014.6901.

13. Wagner, H, Bladt S, Zgainsky EM. Plant drug analysis: a thin layer chromatography atlas. Berlin: Springer. 1984. p. 320. https://doi.org/10.1007/978-3-66202398-3.

14. Kim DH, Je JY.Antimicrobial activity of gallic acid-grafted-chitosan against fish pathogens. Int. J. Carbohydr. Chem. 2015;34(3):163-71. https://doi.org/10.1080/ 07328303.2015.1018993.

15. Sarjit A, Wang Y, Dykes GA. Antimicrobial activity of gallic acid against thermophilic Campylobacter is strain specific and associated with a loss of calcium ions. Food microbial. 2015;46:227-33. https://doi.org/10.1016/.j.fm.2014.08.002 PMid:25475290.

16. Fu R, Zhang Y, Guo Y, Chen F. Chemical composition, antioxidant and antimicrobial activity of chinese tallow tree leaves. Ind.Crop. Prod. 2015;76:374-7. https:// doi.org/10.1016/j.indcrop.2015.07.030.

17. Campos VAC, Perina FJ, Alves E, Sartorelli J, Moura AM, Oliveira DF. Anadenanthera colubrina (Vell.) Brenan produces steroidal substances that are active against Alternaria alternata (Fr.) Keissler and that may bind to oxysterol-binding proteins. Pest.Manag. Sci. 2014;70(12):1815-22.https://doi.org/10.1002/ps.3722 PMid:24408227.

18. Gonçalves AL, Alves Filho $A$, Menezes $H$. Estudo comparativo da atividade antimicrobiana de extratos de algumas arvores nativas. Arq. Inst. Biol. 2005;72(3):353-8

19. Costa EMMB, Barbosa AS, Florentino VGB, Silva JDF, Trovão DMBM, Medeiros ACD. In vitro antimicrobial activity of plants extracts of semi-arid region of Paraíba, PB,Brazil. J. Dental Science 2013;28(4):100-4.

20. Hussain Al, Anwar F, Sherazi, STH, Przybylski R. Chemical composition, antioxidant and antimicrobial activities of Basil (Ocimum basilicum) essential oils depends on seasonal variations. Food Chem. 2008;108(3):986-95. https://doi. org/10.1016/j.foodchem.2007.12.010 PMid:26065762.

21. Araújo TAS, Castro VTNA, Solon LGS, Da Silva GA, Almeida MG, Costa JGM Amorim ELC, Albuquerque UP. Does rainfall affect the antioxidant capacity and production of phenolic compounds of an important medicinal species? Ind Crop. Prod. 2015;76:550-6. https://doi.org/10.1016/j.indcrop.2015.07.008.

22. Miao Ma, Cheng-Lin Hong, Shu-Qing An, Bo Li. Seasonal, spatial and interspecific variation in quercetin in Apocynum venetum and Poacynum hendersonii, 
Chinese traditional herbal teas. J. Agric. Food Chem. 2003;51(8):2390-3. https:// doi.org/10.1021/jf021055i PMid:12670186.

23. Nishiwaka DO, Peres DD, Oliveira CA, Silva VLR, Kaneko TM, Velasco MVR, Baby AR. Stability and efficacy of sunscreens containing inorganic filters and quercetin. Biomed Biopharm. Res. 2013;1(10):91-100
24. Agati G, Biricolti S, Guidi L, Ferrini F, Fini A, Tattini M. The biosynthesis of flavonoids is enhanced similarly by UV radiation and root zone salinity in L. vulgare leaves. J Plant Physiol. 2011;168(3):204-12. https://doi.org/10.1016/j. jplph.2010.07.016 PMid:20850892.
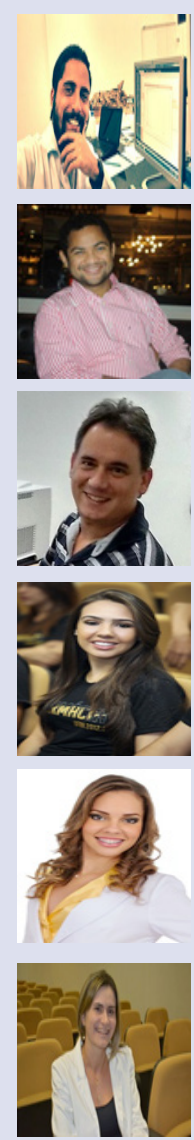

Silvana Maria Zucolotto Langassner has Bachelor, Master and PhD Degree in Pharmaceutical Sciences from Universidade Federal de Santa Catarina (UFSC). Currently, she is Professor at Universidade Federal do Rio Grande do Norte (UFRN). Her research is focused in the chemical characterization of natural products.

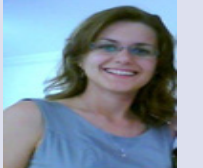

Raquel Brandt Giordani has Bachelor, Master and PhD Degree in Pharmaceutical Sciences from Universidade Federal do Rio Grande do Sul (UFRGS). She had a Pos-doc position at UFRGS. Currently, she is Professor at Universidade Federal do Rio Grande do Norte (UFRN).

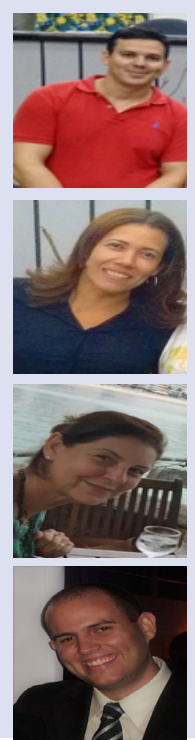

Alexandre Gomes Da Silva has Bachelor in Biological Sciences and Master Degree in Botanic from Universidade Federal Rural de Pernambuco (UFRPE). He holds a PhD in Biological Sciences from Universidade Federal de Pernambuco (UFPE). He has experience in botany, with emphasis on floristics, phytogeography and taxonomy.

Márcia Vanusa da Silva has Bachelor in Agronomy from Universidade Federal Rural de Pernambuco (UFRPE) and Master Degree in Agronomy from Universidade Federal de Lavras (UFL). She holds a PhD in Cellular and Molecular Biology from Universidade Federal do Rio Grande do Sul (UFRGS). Currently, she is Professor at Universidade Federal do Rio Grande do Norte (UFRN).

Maria Tereza dos Santos Correia holds a degree in Industrial Chemistry and MSc in Biochemistry both from the University Federal de Pernambuco (UFPE) and Ph.D. in Biological Sciences (Molecular Biology) from Universidade Federal de São Paulo (UNIFESP). She is Associate Professor at UFPE. She has experience in Biochemistry of macromolecules with emphasis on proteins and molecules from the secondary metabolism of plants. Her major scientific topics are: purification, characterization and applications of proteins (plant and animal) and plant secondary metabolites as well as immobilization of lectins to characterize glycoconjugate.

Rafael Matos Ximenes has Bachelor in Pharmaceutical Sciences from Universidade Federal de Pernambuco (UFPE). His holds a Master and PhD Degree in Pharmacology at Universidade Federal do Ceará (UFC). Currently, she is Professor at UFPE. His Research interest includes chemistry and Ethnopharmacology of Medicinal and aromatic plants from Castinga, mainly those reputed as anti-inflammatory and analgesic.

Cite this Article: Araújo DRC, Silva LCN, Harand W, Fernandes JM, Soares TC, Langassner SMZ, Giordani RB, Ximenes RM, Silva AG, Silva MV, Correia MTS Effects of Rainfall on the Antimicrobial Activity and Secondary Metabolites Contents of Leaves and Fruits of Anadenanthera colubrina from Caatinga Area. Pharmacogn J. 2017:9(4):435-40. 